\title{
Primjena modela SERVQUAL u mjerenju kvalitete usluga $u$ Thalasso wellness centru Opatija
}

1 Suzana Marković

1 Luka Škifić

2 Aleksandar Racz

1 Fakultet za menadžment u turizmu i ugostiteljstvo, Sveučilište u Rijeci

2 Zdravstveno veleučilište Zagreb

\section{Sažetak}

Zdravstveni turizam kompleksan je turistički proizvod koji obuhvaća velik broj specijaliziranih sadržaja i usluga na putovanjima motiviranim potrebom za unapređenjem zdravlja i poboljšanjem kvalitete života. Wellnessturizam kao njegova sastavnica, a posebice medicinski wellness, organizirano je provođenje zdravstveno-preventivnih i kurativnih programa u svrhu prevencije bolesti te očuvanja i unaprjeđenja zdravlja, čije usluge utječu na raznolikost ukupnoga turističkog proizvoda, a time i na bolju prepoznatljivost turističke destinacije na sve zahtjevnijem tržištu.

Cilj ovog rada bio je istražiti očekivanja i percepcija korisnika usluga primjenom modificiranoga modela SERVQUAL.

Istraživanje je provedeno u Thalasso Wellness Centru Opatija na slučajnom uzorku od 87 ispitanika, a prikupljeni podaci analizirani su primjenom metoda deskriptivne i bivarijatne statističke analize.

Rezultati istraživanja potvrdili su empirijsku pretpostavku o adekvatnosti primjene modela SERVQUAL za mjerenje kvalitete usluga wellnessa, jer je dobiven jasan prikaz ukupne kvalitete usluga wellnessa.

Rezultati su nedvosmisleno ukazali na postojanje jaza između percepcija i očekivanja korisnika. S obzirom na to da su najviše prosječne ocjene za percepciju dobile dimenzije opipljivost i pouzdanost kvalitete usluga wellnessa, a najniže osjećajnost ili empatija, u tim je dimenzijama i utvrđen i najveći jaz.

Rezultati empirijskoga istraživanja mogu poslužiti menadžmentu ustanove kao poticaj za opravdanost kontinuiranoga provođenja istraživanja kvalitete usluga wellnessa, zadovoljstva korisnika usluga wellnessa i radnoga zadovoljstva osoblja wellness-centra primjenom i drugih metoda i modela.

Ključne riječi: kvaliteta usluga, kvaliteta usluga wellnessa, zadovoljstvo korisnika, SERVQUAL, Thalasso Wellness Centar Opatija

Datum primitka: 15.05.2020.

Datum prihvaćanja: 01.09.2020.

https://doi.org/10.24141/1/6/2/2

Adresa za dopisivanje: A: Sveučilište u Rijeci, Fakultet za menadžment u turizmu i ugostiteljstvu, Opatija, Hrvatska

E-pošta: suzanam@fthm.hr

T: +385992455901 


\section{Uvod}

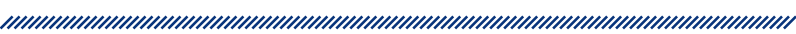

Zdravstveni turizam jedan je od najvažnijih trendova turističkih putovanja, čemu znatnije pridonosi povećana svijest ljudi o brizi za vlastito zdravlje, koje je u današnjim uvjetima života i rada često narušeno od ubrzanoga načina života, odnosno povećanja stresnih situacija. Osim toga, razlog porasta zanimanja za turistička putovanja radi očuvanja zdravlja moguće je ostvariti i zbog povećanja slobodnoga vremena i prihoda stanovništva. Wellness-turizam, kao potkategorija zdravstvenoga turizma, sadrži ukupnost svih odnosa i fenomena koji proizlaze iz putovanja i boravka ljudi čiji je glavni motiv očuvati ili unaprijediti zdravlje. Korisnici usluga wellnessa srednje su dobi, obrazovani su i rade na mjestima s visokim primanjima, zahtjevni su i očekuju visoku kvalitetu usluga. Korisnici zdravstvenih usluga i usluga wellnessa mogu biti tradicionalni korisnici zdravstvenih tretmana, poslovni ljudi i sudionici kongresa te mlade obitelji na odmoru. Wellness-turizam omogućava relativno dulji boravak klijenata u zdravstveno-turističkoj odnosno wellness-destinaciji, čime se produžava turistička sezona, a time i bolja iskorištenost smještajnih kapaciteta. Tome može pridonijeti i povezivanje wellness-turizma s drugim gospodarskim granama, primjerice s agroturizmom, kongresnim turizmom, kulturnim turizmom i dr.

Kvalitetna usluga wellnessa utječe na raznolikost ukupnoga turističkog proizvoda, a time i na bolju prepoznatljivost destinacije na sve zahtjevnijem tržištu wellness-turizma. Budući da se usluge wellnessa temelje na organiziranom korištenju prirodnih ljekovitih činitelja okoline, njima se čuvaju prirodni resursi okruženja destinacije. Stoga razvoj usluga wellnessa ima vrlo važnu ulogu u ukupnom turističkom proizvodu, pozitivno utječe na gospodarski razvoj i na smanjenje rastućih zdravstvenih troškova. Strategijom razvoja zdravstvenoga turizma u Republici Hrvatskoj do 2020. prepoznata je važnost njegova razvoja, no u praksi se veoma malo radi na nužnom prilagođavanju postojećih smještajnih kapaciteta u lječilištima, toplicama i specijalnim bolnicama.

Osim toga, kvalitetan razvoj zdravstvenoga turizma zahtijeva informatizaciju, integraciju elektroničkoga i mobilnoga poslovanja, pružanje jedinstvene usluge, povoljnije cijene u odnosu na konkurentna turistička tržišta te kvalificirane i cijenjene djelatnike, čime se osi- gurava produženje turističke sezone na cijelu godinu. Odgovarajuće unaprjeđenje kvalitete usluga u zdravstvenom i wellness-turizmu, a prema tome i pružanju usluga wellnessa, može se postići ne samo djelovanjem zdravstvenih i turističkih ustanova u borbi s konkurencijom i privlačenjem klijenata nego i zakonom propisanih jasnih i transparentnih uvjeta poslovanja.

\section{Problem i predmet istraživanja}

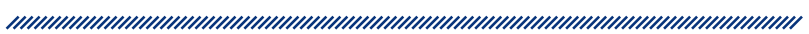

Zdravstveni i wellness-turizam, kao posebni oblici turizma, kao i usluge wellnessa, sadrže veliki potencijal razvoja i u Hrvatskoj pa je stoga važno istraživanje načina njihova daljnjeg razvoja kroz koncept mjerenja kvalitete usluga wellnessa. Zadovoljstvo klijenata pruženim uslugama wellnessa jedno je od najvažnijih elemenata promocije, jer zadovoljan klijent može donijeti samo pozitivnu promidžbu kvalitete usluga wellnessa.

U skladu s navedenim, predmet istraživanja ovoga rada bilo je mjerenje koncepta kvalitete usluga wellnessa na primjeru Thalasso Wellness Centra Opatija. Rezultati istraživanja zadovoljstva klijenata u Thalasso Wellness Centru Opatija mogu pridonijeti poboljšanju uvjeta poslovanja u smislu orijentacije prema iznimno zahtjevnom tržištu wellness-turizma te eventualno mogu ukazati na moguće nedostatke o kvaliteti usluga wellnessa i pružiti korisne informacije menadžmentu o mogućnostima unaprjeđenja kvalitete usluga wellnessa. Povećanjem kvalitete usluga wellnessa u Thalasso Wellness Centru Opatija može se utjecati na povećanje konkurentnosti i prepoznatljivosti ustanove i turističke destinacije na sve zahtjevnijem domaćem i međunarodnom tržištu wellness-turizma.

Parasuraman i suradnici definirali su model SERVQUAL mjerenja kvalitete usluga usporedbom očekivanja klijenta od usluge koja bi se trebala obaviti s percepcijom usluge koja se stvarno obavila. ${ }^{1}$ Mjerna ljestvica SERVQUAL temelji se na jazu između očekivanja i percepcije klijenta. ${ }^{2}$ SERVQUAL je model koji pruža odgovarajući sadržaj za promišljanje o tome koji elementi usluge utječu na njezinu kvalitetu pa se stoga elementi takvoga pristupa primjenjuju u različitim studijama o zadovoljstvu klijenata u privatnim i javnim uslužnim djelatnostima, a njegovom pravilnom primjenom može se doći do korisnih podataka. Ovaj model sadržavao je izvorno deset dimenzija 
kvalitete usluge: opipljivost, pouzdanost, susretljivost, komunikaciju s klijentom, kredibilitet, sigurnost, uljudnost, razumijevanje, poznavanje kupca i pristupačnost, koje su nakon provedenih istraživanja smanjene na pet dimenzija: opipljivost, pouzdanost, susretljivost, sigurnost i empatiju. ${ }^{1,2} \mathrm{U}$ teoriji se tih pet dimenzija obično upotrebljava kao akronim RATER (engl. Reliability, Assurance, Tangibles, Empathy, Responsiveness. ${ }^{3}$

Prethodno provedena istraživanja pokazala su da model SERVQUAL daje jasnu sliku o kvaliteti usluga u hotelskim wellness-centrima te da stoga može pružiti korisne informacije menadžmentu, kao i da je model SERVQUAL za mjerenje kvalitete usluga pouzdan instrument za mjerenje kvalitete usluga wellnessa. ${ }^{5-10}$ Primjenom modificiranog modela SERVQUAL za mjerenje kvalitete usluga provedeno je istraživanje kvalitete usluga wellnessa, ocijenjena su očekivanja i percepcije klijenata Thalasso Wellness Centra Opatija te su doneseni zaključci o kvaliteti usluga wellnessa i predložene moguće smjernice za daljnje unaprjeđenje kvalitete usluga wellnessa.

\section{Svrha i ciljevi istraživanja}

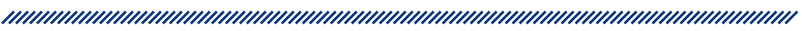

U skladu s postavljenim problemom, određeni su sljedeći ciljevi istraživanja:

1. metodom deskriptivne statistike ocijeniti očekivanja i percepcije korisnika usluga wellnessa

2. utvrditi sociodemografske karakteristike klijenata (metodama deskriptivne statistike)

3. ispitati očekivanja i percepciju kvalitete usluga wellnessa (metodama deskriptivne statistike)

4. izračunati SERVQUAL jaz i ocijeniti kvalitetu usluga wellnessa (metodama deskriptivne statistike)

5. utvrditi važnost dimenzija kvalitete usluga wellnessa (metodama deskriptivne statistike)

6. utvrditi značajnost razlike u prosječnim ocjenama za očekivanu vrijednost u odnosu na dob ispitanika (t-test)

7. utvrditi značajnost razlike u prosječnim ocjenama za percipiranu vrijednost u odnosu na spol ispitanika (t-test).

$\mathrm{Na}$ temelju rezultata istraživanja na kraju rada namjera je autora bila predložiti moguće smjernice unaprjeđenja kvalitete usluga wellnessa u Thalasso Wellness Centru Opatija.

\section{Hipoteze}

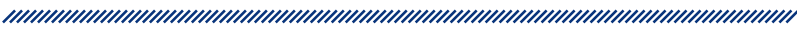

Glavna hipoteza: Na temelju teorijskih i empirijskih spoznaja o kvaliteti usluga wellnessa i njihova mjerenja moguće je primjenom modela SERVQUAL dobiti uvid u očekivanja, potrebe i želje korisnika usluga wellnessa, utvrditi stupanj njihova zadovoljstva kvalitetom usluga wellnessa te tako dobivenu informaciju iskoristiti radi poboljšanja kvalitete usluga wellnessa u Thalasso Wellness Centru Opatija u cilju podizanja njegove konkurentnosti i prepoznatljivosti na sve zahtjevnijem tržištu usluga wellnessa.

$\mathrm{Na}$ temelju definirane glavne hipoteze postavljene su i pomoćne hipoteze:

H1: Postoji značajan jaz između percipirane i očekivane kvalitete usluga wellnessa.

H2: Klijenti percipiraju individualan pristup i razumijevanje njihovih specifičnih problema.

H3: Klijenti očekuju brze, pravodobne i korektne usluge, čistoću i urednost centra i djelatnika.

H4: Postoji statistički značajna razlika u očekivanjima i percepciji s obzirom na dob klijenata.

H5: Ne postoji statistički značajna razlika u percepciji s obzirom na spol klijenata.

\section{Uzorak i metodologija istraživanja}

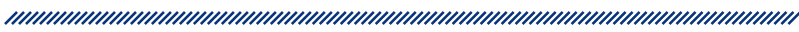

Primarni podaci prikupljeni su metodom anketiranja primjenom modificiranog modela SERVQUAL za mjerenje kvalitete usluga wellnessa u Thalasso Wellness Centru Opatija. Anketni upitnik pripremljen je na hrvatskom i engleskom jeziku te se sastoji od četiri dijela. Prvi je dio sastavljen od 26 tvrdnji povezanih s očekivanjima klijenata, dok se u drugom dijelu nalazi 26 tvrdnji povezanih s percepcijom klijenata. U izvornom je obliku modelSERVQUAL sadržavao 22 tvrdnje koje su za potrebe ovog istraživanja bile dopunjene četirima tvrdnjama iz dimenzije opipljivih karakteristika kvalitete usluga wellnessa, koje su definirana na temelju specifične skupine korisnika usluga wellnessa, i to: 
- tvrdnja br. 4: Ugodan inventar i namještaj izvrsnog Thalasso Wellness Centra.

- tvrdnja br. 5: Čistoća pribora i uređaja Thalasso Wellness Centra.

- tvrdnja br. 6: Čistoća i urednost izvrsnog Thalasso Wellness Centra.

- tvrdnja br.7: Raspolaganje opremom i objektima Thalasso Wellness Centra.

U odnosu na dimenziju opipljivosti usluga wellnessa, odnosno prostor i opremu, izgled zaposlenika te razumljivost promotivnog $\mathrm{i}$ informacijskog materijala $\mathrm{u}$ anketnom upitniku, bilo je ponuđeno osam tvrdnji. $U$ odnosu na dimenziju pouzdanosti usluga wellnessa, odnosno obavljanje obećane usluge uredno i na vrijeme, bilo je ponuđeno pet tvrdnji. U odnosu na dimenziju susretljivosti osoblja, odnosno pomaganje klijentima i pružanje brze usluge, u anketnom upitniku bilo je ponuđeno pet tvrdnji. U odnosu na dimenziju sigurnosti, odnosno stjecanja povjerenja i pouzdanja klijenata u osoblje wellness-centra, bile su ponuđene tri tvrdnje. U odnosu na dimenziju suosjećanja, odnosno pažljivog i pojedinačnog pružanja usluga wellnessa klijentima, bilo je ponuđeno pet tvrdnji. Klijenti su na Likertovoj ljestvici od sedam stupnjeva mogli izraziti stupanj slaganje s pojedinom tvrdnjom u rasponu od „u potpunosti se ne slažem”, što je označeno brojkom 1 , do „u potpunosti se slažem", što je označeno brojkom 7 .

Zaključno, u trećem dijelu bila su postavljena pitanja o sociodemografskim karakteristikama ispitanika (država i mjesto stalnog boravka klijenta, spol, dob, zanimanje, obrazovanje, učestalost dolaska u wellness-centar i grad u kojem se nalazi wellness-centar).

Prikupljanje primarnih podataka, radi istraživanja kvalitete usluga wellnessa bilo je provedeno na uzorku slučajno odabranih klijenata Thalasso Wellness Centra Opatija, kojima su u razdoblju od prosinca 2016. do listopada 2017. bili podijeljeni anketni upitnici prilikom njihova dolaska i smještaja u Thalasso Wellness Centar Opatija, a ispunjene obrasce klijenti su predavali po odjavi boravka. Anketni upitnik bio je dostupan na hrvatskom i engleskom jeziku, pri čemu je na kraju istraživanja bilo prikupljeno $\mathrm{N}=87$ ispravno ispunjenih anketnih upitnika, od kojih su 15 na engleskom jeziku popunili strani ispitanici.

Prikupljeni primarni podaci analizirani su primjenom programa za statističku obradu i analizu podataka SPSS. $U$ analizi podataka primijenjene su metode univarijatne i bivarijatne statističke analize. Metode de- skriptivne statistike (postoci, aritmetička sredina, grafičko prikazivanje) primijenjene su za opisivanje uzorka i izračun prosječnih ocjena kvalitete usluga (očekivanja i percepcije). Statistička značajnost razlika između prosječnih ocjena procijenjena je primjenom bivarijatne statističke analize (t-test).

\section{Rezultati istraživanja}

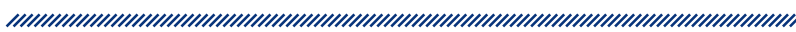

U Thalasso Wellness Centru Opatija provedeno je istraživanje na uzorku od $\mathrm{N}=87$ korisnika usluga wellnessa, od kojih je domaćih korisnika bilo $45 \%$, a stranih korisnika $55 \%$ (tablica 1). Prema sociodemografskim podacima, 15 stranih ispitanika svoje je odgovore dalo na anketnim upitnicima sastavljenima na engleskom jeziku, a njih osam ih se izjasnilo da su norveški državljani, dok je jedan ispitanik koji je bio iz Slovenije odgovore dao na upitniku sastavljenom na hrvatskom jeziku. Domaćih korisnika bilo je 71 te in se 61 izjasnilo o mjestu prebivališta, tako da in je iz Zagreba bilo 11, Rijeke devet, Opatije četiri, Osijeka i Zadra po dva, dok je po jedan korisnik ispitanik bio iz Križevaca, Koprivnice, Umaga, Fažane, Rovinja, Vineža, Raše, Pazina, Ogulina, Gospića, Ključa, Križa, Ičića, Kastva, Krka, Splita i Dubrovnika, a jedan je ispitanik izjavio da ima prebivalište u Innsbrucku u Austriji.

Prema navedenim podacima o mjestu prebivališta domaćih klijenata može se zaključiti da je većina ispitanika iz većih gradskih središta te iz gradova i mjesta koji gravitiraju prema Opatiji u kojoj se nalazi Thalasso Wellness Centar Opatija.

Prema sociodemografskim podacima prikazanima u tablici 1 , većina klijenata bila je muškog spola $(71,3 \%)$ te su pripadali dobnoj skupini starijoj od 56 godina ( $33 \%$ ). Ispitanika su većinom bili umirovljenici $(27,8 \%)$, dok je visoko obrazovanje ili fakultet imalo $33,1 \%$ korisnika. Prema učestalosti boravka u gradu, većina ispitanika boravila je u Opatiji dva ili više puta (51,3\%), dok se manji postotak ispitanika koristio uslugama wellness-centra samo jedanput (27,8\%), a nikada $24,4 \%$ ispitanika.

Prema rezultatima na uzorku od $\mathrm{N}=87$ ispitanika prikazanima tablicom 2, utvrđene su prosječne ocjene za očekivanja i percepciju kvalitete usluga wellnessa, tako da je aritmetička sredina za očekivanja imala raspon od 6,35 do 6,89 , a ukupna prosječna ocjena za očekivanja iznosila je 6,65, što ukazuje na visoka očekivanja korisnika u vezi s kvalitetom usluga wellnessa. 


\section{Tablica 1. Profil ispitanika ( $\mathbf{N}=\mathbf{8 7})$}

\begin{tabular}{|c|c|c|}
\hline Karakteristika & $\begin{array}{l}\text { Apsolutne } \\
\text { frekvencije }\end{array}$ & $\begin{array}{l}\text { Relativne } \\
\text { frekvencije }\end{array}$ \\
\hline \multicolumn{3}{|l|}{ SPOL } \\
\hline muški & 62 & 71,3 \\
\hline ženski & 25 & 28,7 \\
\hline \multicolumn{3}{|l|}{ DOBNA SKUPINA } \\
\hline$<25$ godina & 4 & 3,5 \\
\hline $26-35$ godina & 2 & 1,7 \\
\hline $36-45$ godina & 3 & 2,6 \\
\hline $46-55$ godina & 26 & 22,6 \\
\hline $56-65$ godina & 38 & 3,3 \\
\hline 66 i više godina & 14 & 12,2 \\
\hline \multicolumn{3}{|l|}{ ZANIMANJE } \\
\hline privatni poduzetnik & 7 & 6,9 \\
\hline menadžer & 7 & 6,9 \\
\hline administracija & 4 & 3,5 \\
\hline tehnički poslovi & 8 & 6,9 \\
\hline radnik & 1 & 0,8 \\
\hline student/učenik & 5 & 0,8 \\
\hline umirovljenik & 32 & 27,8 \\
\hline nezaposlen & 1 & 0,8 \\
\hline ostalo & 10 & 8,7 \\
\hline \multicolumn{3}{|l|}{ OBRAZOVANJE } \\
\hline osnovna škola ili niže & 3 & 2,6 \\
\hline srednja škola & 37 & 32,2 \\
\hline visoka škola ili fakultet & 38 & 33,1 \\
\hline $\begin{array}{l}\text { magisterij znanosti ili } \\
\text { doktorat znanosti }\end{array}$ & 3 & 2,6 \\
\hline ništa od navedenog & 0 & 0 \\
\hline \multicolumn{3}{|l|}{$\begin{array}{l}\text { BORAVAK U GRADU } \\
\text { WELLNESS-CENTRA }\end{array}$} \\
\hline nikada & 10 & 8,7 \\
\hline jedanput & 18 & 15,7 \\
\hline dva ili više puta & 59 & 51,3 \\
\hline \multicolumn{3}{|l|}{$\begin{array}{l}\text { BORAVAK U WELLNESS- } \\
\text { CENTRU }\end{array}$} \\
\hline nikada & 28 & 24,4 \\
\hline jedanput & 32 & 27,8 \\
\hline dva ili više puta & 27 & 23,5 \\
\hline
\end{tabular}

Prosječne ocjene za percepciju imale su raspon od 6,19 do 6,69 pa je ukupna prosječna ocjena za percepciju bila 6,44 , što je relativno vrlo visoka percepcija kvalitete usluga wellnessa.

$\mathrm{Na}$ temelju provedene analize prikupljenih podataka izračunan je SERVQUAL jaz prikazan tablicom 4, koji je dobar pokazatelj ukupne kvalitete usluga wellnessa, a dobiven je na temelju razlike prosječnih ocjena za očekivanja i percepciju. Negativan jaz povezan je s 24 varijable te se može zaključiti da je za te varijable percepcija bila niža od očekivanja, no razlike nisu bile statistički značajne, iz čega se moglo zaključiti da postoji mogućnost za poboljšanje kvalitete usluga wellnessa u Thalasso Wellness Centru Opatija.

Pozitivan jaz $(0,1)$ imala je varijabla „Izvrsni Thalasso Wellness Centar brižljivo vodi računa o gostima”, dok su najniži jaz $(-0,1)$ imale varijable „Izvrsni Thalasso Wellness Centar ima ugodan inventar i namještaj”, „U izvrsnom Thalasso Wellness Centru obećanja se izvršavaju na vrijeme”, „osoblje izvrsnog Thalasso Wellness Centra uvijek nađe vremena odgovoriti gostu na pitanje" te „Zahvaljujući svojem znanju, osoblje u izvrsnog Thalasso Wellness Centra zna odgovoriti na pitanja gosta”, po čemu se moglo zaključiti da je kvaliteta pruženih usluga wellnessa bila vrlo blizu očekivanoj.

Varijable „Osoblje izvrsnog Thalasso Wellness Centra gostima pruža brzu (promptnu) uslugu” i „Osoblje izvrsnog Thalasso Wellness Centra dodatno se trudi kako bi zadovoljilo potrebe gostiju" imale su jaz 0 , na temelju čega se moglo zaključiti da su za te varijable očekivanja korisnika usluga wellnessa bile jednake njihovoj percepciji kvalitete te proizlazi da je u odnosu na tu vrstu usluga wellnessa prihvatljiva njihova kvaliteta.

Najveći SERVQUAL jaz $(-0,53)$ imale su varijable o atraktivnom izgledu zgrada i prostorija, čistoći pribora i uređaja te pružanju individualizirane pažnje od strane Thalasso Wellness Centra te jaz $(-0,4)$ u odnosu na varijablu urednosti i čistoće Thalasso Wellness Centra.

Prema dimenzijama pruženih usluga prikazanima tablicom 5 , najveće prosječne ocjene za očekivanja imala je dimenzija opipljivost $(6,7)$, dok su ostale dimenzije imale prosječnu ocjenu 6,6. Najviši jaz imala je dimenzija opipljivost $(-0,3)$, a najnižu dimenzije pouzdanost, susretljivost i sigurnost $(-0,1)$. Prema analiziranim podacima, značajniji jaz između očekivanja i percepcije pokazala je samo varijabla „brižljivo vođenje računa o gostima” $(0,1)$ te varijable "dodatan trud osoblja kako bi se zadovoljile potrebe gostiju” i „pružanje promptne usluge gostima" (0). 


\begin{tabular}{|c|c|c|c|}
\hline \multirow[b]{2}{*}{ R. br. } & \multirow[b]{2}{*}{ TVRDNJA } & \multicolumn{2}{|c|}{ Očekivanja } \\
\hline & & $\begin{array}{l}\text { Aritmetička } \\
\text { sredina }\end{array}$ & $\begin{array}{c}\text { Standardna } \\
\text { devijacija }\end{array}$ \\
\hline 1. & Moderna oprema & 6,84 & 0,686 \\
\hline 2. & Atraktivan izgled zgrada i prostorija & 6,72 & 0,521 \\
\hline 3. & Čistoća i urednost osoblja & 6,89 & 0,348 \\
\hline 4. & Ugodan inventar i namještaj & 6,39 & 0,836 \\
\hline 5. & Čisti pribor i uređaji & 6,82 & 0,522 \\
\hline 6. & Urednost i čistoća Thalasso Wellness Centra & 6,76 & 0,524 \\
\hline 7. & Raspolaganje opremom i objektima u skladu s uslugama koje se pružaju & 6,76 & 0,627 \\
\hline 8. & Pravodobno izvršavanje obećanja & 6,49 & 0,824 \\
\hline 9. & Razumijevanje problema korisnika & 6,79 & 0,626 \\
\hline 10. & Korektno pružanje usluga već u prvom pokušaju & 6,77 & 0,496 \\
\hline 11. & Pružanje usluga u obećanom vremenu & 6,71 & 0,639 \\
\hline 12. & Pouzdane i besprijekorne usluge & 6,79 & 0.64 \\
\hline 13. & Pružanje brzih usluga & 6,5 & 0,731 \\
\hline 14. & Spremno pomaganje korisnicima & 6,72 & 0,708 \\
\hline 15. & Odvajanje vremena za odgovore korisnicima & 6,55 & 0,533 \\
\hline 16. & Pružanje individualizirane pažnje od strane osoblja & 6,7 & 0,624 \\
\hline 17. & Stvaranje odnosa povjerenja prema korisnicima & 6,75 & 0,707 \\
\hline 18. & Ljubaznost osoblja prema korisnicima & 6,67 & 0,678 \\
\hline 19. & Odgovori osoblja na pitanja korisnika u skladu sa znanjem & 6,46 & 0,567 \\
\hline 20. & Pružanje korisnicima osjećaja sigurnosti i bezbrižnosti & 6,68 & 0,568 \\
\hline 21. & Pružanje profesionalnih usluga & 6,35 & 0,763 \\
\hline 22. & Pružanje individualizirane pažnje od strane Thalasso Wellness Centra & 6,89 & 0,347 \\
\hline 23. & Brižljivo vođenje računa o zahtjevima i potrebama korisnika & 6,36 & 1,087 \\
\hline 24. & Razumijevanje specifičnih problema korisnika & 6,46 & 0,905 \\
\hline 25. & Brzo rješavanje problema korisnika & 6,48 & 0,673 \\
\hline \multirow[t]{2}{*}{26.} & Dostupnost i jasnoća informacija o Thalasso Wellness Centru & 6,59 & 0,687 \\
\hline & Ukupna prosječna ocjena & 6,65 & \\
\hline
\end{tabular}

Najširi jaz imale su varijable „atraktivan izgled zgrade i prostorija wellness-centra”, „čistoća pribora i uređaja u wellness-centru” te „pružanje gostima individualizirane pažnje" $(-0,5)$, što ipak nije bilo statistički značajno.

Pet najviših prosječnih ocjena za ljestvicu očekivanja prikazanih tablicom 6 bile su povezane s čistoćom, urednošću i prikladnom odjećom osoblja wellness-centra i pružanja gostima individualizirane pažnje $(6,89)$ te čistoće i urednosti pribora i uređaja $(6,82)$ i wellness-centra $(6,76)$, kao i pružanja usluge korektno već u prvom pokušaju $(6,77)$. Čistoća, urednost i prikladna odjeća osoblja well- ness-centra ispunile su očekivanja korisnika, jer su iste prosječne ocjene za očekivanja i percepciju $(6,69)$. Najviše prosječne ocjene za percepciju ispitanika bile su povezane s dodatnim trudom osoblja kako bi se zadovoljile potrebe gostiju $(6,7)$, stručnim pružanjem usluge osoblja u wellness-centru $(6,54)$ te pouzdanih i besprijekornih usluga u wellness-centru $(6,59)$.

Četiri najniže prosječne ocjene za ljestvicu očekivanja ispitanika odnosile su se na ugodan inventar i namještaj $(6,39)$, stručno pružanje usluge, razumijevanje specifičnih potreba ispitanika te brižljivo vođenje računa o 


\begin{tabular}{|c|c|c|c|}
\hline \multirow[b]{2}{*}{ R. br. } & \multirow[b]{2}{*}{ TVRDNJA } & \multicolumn{2}{|c|}{ Percepcija } \\
\hline & & $\begin{array}{l}\text { Aritmetička } \\
\text { sredina }\end{array}$ & $\begin{array}{c}\text { Standardna } \\
\text { devijacija }\end{array}$ \\
\hline 1. & Moderna oprema & 6,58 & 0,687 \\
\hline 2. & Atraktivan izgled zgrada i prostorija & 6,19 & 0,497 \\
\hline 3. & Čistoća i urednost osoblja & 6,69 & 0,348 \\
\hline 4. & Ugodan inventar i namještaj & 6,28 & 0,841 \\
\hline 5. & Čisti pribor i uređaji & 6,29 & 0,524 \\
\hline 6. & Urednost i čistoća Thalasso Wellness Centra & 6,35 & 0,441 \\
\hline 7. & Raspolaganje opremom i objektima u skladu s uslugama koje se pružaju & 6,47 & 0,682 \\
\hline 8. & Pravodobno izvršavanje obećanja & 6,39 & 0,785 \\
\hline 9. & Razumijevanje problema korisnika & 6,58 & 0,642 \\
\hline 10. & Korektno pružanje usluga već u prvom pokušaju & 6,38 & 0,557 \\
\hline 11. & Pružanje usluga u obećanom vremenu & 6,37 & 0,627 \\
\hline 12. & Pouzdane i besprijekorne usluge & 6,59 & 0,625 \\
\hline 13. & Pružanje brzih usluga & 6,5 & 0,763 \\
\hline 14. & Spremno pomaganje korisnicima & 6,47 & 0,677 \\
\hline 15. & Odvajanje vremena za odgovore korisnicima & 6,68 & 0,923 \\
\hline 16. & Pružanje individualizirane pažnje od strane osoblja & 6,7 & 0,577 \\
\hline 17. & Stvaranje odnosa povjerenja prema korisnicima & 6,49 & 0,559 \\
\hline 18. & Ljubaznost osoblja prema korisnicima & 6,47 & 0,623 \\
\hline 19. & Odgovori osoblja na pitanja korisnika u skladu sa znanjem & 6,36 & 0,726 \\
\hline 20. & Pružanje korisnicima osjećaja sigurnosti i bezbrižnosti & 6,49 & 0,744 \\
\hline 21. & Pružanje profesionalnih usluga & 6,54 & 0,873 \\
\hline 22. & Pružanje individualizirane pažnje od strane Thalasso Wellness Centra & 6,38 & 0,640 \\
\hline 23. & Brižljivo vođenje računa o zahtjevima i potrebama korisnika & 6,26 & 0,729 \\
\hline 24. & Razumijevanje specifičnih problema korisnika & 6,21 & 0,796 \\
\hline 25. & Brzo rješavanje problema korisnika & 6,29 & 1,073 \\
\hline \multirow[t]{2}{*}{26.} & Dostupnost i jasnoća informacija o Thalasso Wellness Centru & 6,46 & 0,797 \\
\hline & Ukupna prosječna ocjena & 6,44 & \\
\hline
\end{tabular}

gostima $(6,35)$, dok su se četiri najniže prosječne ocjene za ljestvicu percepcije ispitanika odnosile na ugodan inventar i namještaj $(6,28)$, čistoću pribora i uređaja $(6,29)$, brzo rješavanje problema gostiju $(6,29)$ i brižljivo vođenje računa o gostima $(6,21)$, po čemu možemo zaključiti da ispitanici nisu bili zadovoljni inventarom i namještajem, čistoćom pribora i uređaja, da im nije pruženo dovoljno brižne pažnje te da osoblje wellnesscentra nije brzo rješavalo njihove probleme (tablica 7).

Na temelju provedenog istraživanja moglo se zaključiti da su rezultati potvrdili da situacijski činitelji, odnosno izgled, ponašanje, čistoća, urednost i prikladna odjeća osoblja, pravodobno i korektno izvršavanje usluga, pomaganje korisnicima, pružanje individualizirane pažnje, ljubaznost osoblja, razumijevanje specifičnih potreba gostiju, primjena suvremene tehnologije, te dizajn objekta i okoliša wellness-centra znatno utječu na ocjenu percepcije kvalitete usluga wellnessa te da se zadovoljstvo korisnika moglo povezati s tim dijelovima usluga wellnessa.

Iz navedenih rezultata mogu se razmotriti i postavljene pomoćne hipoteze. 


\section{Tablica 4. Rezultati deskriptivne statističke analize - SERVQUAL tvrdnje i SERVQUAL jaz}

\begin{tabular}{|c|c|c|c|c|}
\hline R. br. & TVRDNJA & OČEKIVANJA & PERCEPCIJA & $\begin{array}{l}\text { SERVQUAL } \\
\text { JAZ }\end{array}$ \\
\hline & & $\begin{array}{l}\text { aritmetička } \\
\text { sredina }\end{array}$ & $\begin{array}{l}\text { aritmetička } \\
\text { sredina }\end{array}$ & $P-0$ \\
\hline 1. & Moderna oprema & 6,84 & 6,58 & $-0,26$ \\
\hline 2. & Atraktivan izgled zgrada i prostorija & 6,72 & 6,19 & $-0,53$ \\
\hline 3. & Urednost, čistoća i prikladna odjeća osoblja & 6,89 & 6,69 & $-0,20$ \\
\hline 4. & Ugodan inventar i namještaj & 6,39 & 6,28 & $-0,11$ \\
\hline 5. & Čisti pribor i uređaji & 6,82 & 6,29 & $-0,53$ \\
\hline 6. & Urednost i čistoća Thalasso Wellness Centra & 6,76 & 6,35 & $-0,41$ \\
\hline 7. & $\begin{array}{c}\text { Raspolaganje opremom i objektima u skladu s uslugama koje se } \\
\text { pružaju }\end{array}$ & 6,76 & 6,47 & $-0,29$ \\
\hline 8. & Pravodobno izvršavanje obećanja & 6,49 & 6,39 & $-0,10$ \\
\hline 9. & Razumijevanje problema korisnika & 6,76 & 6,36 & $-0,40$ \\
\hline 10. & Korektno pružanje usluga već u prvom pokušaju & 6,79 & 6,58 & $-0,21$ \\
\hline 11. & Pružanje usluga u obećanom vremenu & 6,77 & 6,38 & $-0,39$ \\
\hline 12. & Pouzdane i besprijekorne usluge & 6,71 & 6,37 & $-0,34$ \\
\hline 13. & Pružanje brzih usluga & 6,79 & 6,59 & $-0,21$ \\
\hline 14. & Spremno pomaganje korisnicima & 6,72 & 6,47 & $-0,25$ \\
\hline 15. & Odvajanje vremena za odgovore korisnicima & 6,55 & 6,68 & 0,13 \\
\hline 16. & Pružanje individualizirane pažnje od strane osoblja & 6,7 & 6,7 & 0 \\
\hline 17. & Stvaranje odnosa povjerenja prema korisnicima & 6,75 & 6,49 & $-0,26$ \\
\hline 18. & Ljubaznost osoblja prema korisnicima & 6,67 & 6,47 & $-0,20$ \\
\hline 19. & Odgovori osoblja na pitanja korisnika u skladu sa znanjem & 6,46 & 6,36 & $-0,10$ \\
\hline 20. & Pružanje korisnicima osjećaja sigurnosti i bezbrižnosti & 6,68 & 6,49 & $-0,19$ \\
\hline 21. & Pružanje profesionalnih usluga & 6,35 & 6,54 & 0,19 \\
\hline 22. & Pružanje individualizirane pažnje od strane Thalasso Wellness Centra & 6,89 & 6,38 & $-0,51$ \\
\hline 23. & Brižljivo vođenje računa o zahtjevima i potrebama korisnika & 6,36 & 6,26 & $-0,10$ \\
\hline 24. & Razumijevanje specifičnih problema korisnika & 6,46 & 6,21 & $-0,25$ \\
\hline 25. & Brzo rješavanje problema korisnika & 6,48 & 6,29 & $-0,19$ \\
\hline 26. & Dostupnost i jasnoća informacija o Thalasso Wellness Centru & 6,59 & 6,46 & $-0,13$ \\
\hline & Ukupna prosječna ocjena & 6,65 & 6,44 & \\
\hline
\end{tabular}

Tablica 5. Rezultati deskriptivne statističke analize - SERVQUAL dimenzije i SERVQUAL jaz

\begin{tabular}{|c|c|c|c|}
\hline $\begin{array}{c}\text { DIMENZIJE MODELA } \\
\text { SERVQUAL }\end{array}$ & $\begin{array}{c}\text { LJESTVICA } \\
\text { OČEKIVANJA }\end{array}$ & $\begin{array}{c}\text { LJESTVICA } \\
\text { PERCEPCIJE }\end{array}$ & $\begin{array}{c}\text { SERVQUAL } \\
\text { JAZ }\end{array}$ \\
\hline & Prosječna ocjena & Prosječna ocjena & $-0,3$ \\
\hline Opipljivost & 6,7 & 6,4 & $-0,1$ \\
\hline Pouzdanost & 6,6 & 6,5 & $-0,1$ \\
\hline Susretljivost & 6,6 & 6,5 & $-0,1$ \\
\hline Sigurnost & 6,6 & 6,5 & $-0,2$ \\
\hline Suosjećanje & 6,6 & 6,4 & \\
\hline
\end{tabular}




\begin{tabular}{|c|c|c|c|c|c|}
\hline R. br. & Tvrdnja & $\begin{array}{l}\text { Aritmetička } \\
\text { sredina }\end{array}$ & R. br. & Tvrdnja & $\begin{array}{l}\text { Aritmetička } \\
\text { sredina }\end{array}$ \\
\hline $\mathrm{O} 3$ & $\begin{array}{l}\text { Osoblje izvrsnog Thalasso Wellness } \\
\text { Centra mora biti čisto, uredno i } \\
\text { prikladno odjeveno. }\end{array}$ & 6,89 & P3 & $\begin{array}{l}\text { Osoblje izvrsnog Thalasso Wellness } \\
\text { Centra čisto je, uredno i prikladno } \\
\text { odjeveno. }\end{array}$ & 6,69 \\
\hline $\mathrm{O} 22$ & $\begin{array}{l}\text { Osoblje u izvrsnom Thalasso } \\
\text { Wellness Centru treba pružati } \\
\text { gostima individualiziranu pažnju. }\end{array}$ & 6,89 & P16 & $\begin{array}{l}\text { Osoblje izvrsnog Thalasso Wellness } \\
\text { Centra dodatno se trudi kako bi } \\
\text { zadovoljilo potrebe gostiju. }\end{array}$ & 6,7 \\
\hline O5 & $\begin{array}{l}\text { Pribor i uređaji u izvrsnom Thalasso } \\
\text { Wellness Centru moraju biti čisti. }\end{array}$ & 6,82 & $\mathrm{P} 21$ & $\begin{array}{c}\text { Osoblje u izvrsnom Thalasso } \\
\text { Wellness Centru stručno pruža } \\
\text { usluge. }\end{array}$ & 6,54 \\
\hline 06 & $\begin{array}{l}\text { Izvrsni Thalasso Wellness Centar } \\
\text { mora biti čist i uredan. }\end{array}$ & 6,76 & P9 & $\begin{array}{c}\text { Izvrsni Thalasso Wellness Centar } \\
\text { pokazuje razumijevanje za } \\
\text { probleme gostiju. }\end{array}$ & 6,58 \\
\hline 010 & $\begin{array}{l}\text { Izvrsni Thalasso Wellness Centar } \\
\text { mora pružati uslugu korektno već u } \\
\text { prvom pokušaju. }\end{array}$ & 6,77 & P12 & $\begin{array}{l}\text { Usluge u izvrsnom Thalasso } \\
\text { Wellness Centru pouzdane su i } \\
\text { besprijekorne. }\end{array}$ & 6,59 \\
\hline
\end{tabular}

\begin{tabular}{|c|c|c|c|c|c|}
\hline R. br. & Tvrdnja & $\begin{array}{l}\text { Aritmetička } \\
\text { sredina }\end{array}$ & R. br. & Tvrdnja & $\begin{array}{l}\text { Aritmetička } \\
\text { sredina }\end{array}$ \\
\hline $\mathrm{O} 4$ & $\begin{array}{c}\text { Izvrsni Thalasso Wellness Centar } \\
\text { mora imati ugodan inventar i } \\
\text { namještaj. }\end{array}$ & 6,39 & P24 & $\begin{array}{l}\text { Izvrsni Thalasso Wellness Centar } \\
\text { brižljivo vodi računa o gostima. }\end{array}$ & 6,21 \\
\hline 021 & $\begin{array}{l}\text { Osoblje u izvrsnom Thalasso } \\
\text { Wellness Centru mora stručno } \\
\text { pružati usluge. }\end{array}$ & 6,35 & P4 & $\begin{array}{l}\text { Izvrsni Thalasso Wellness Centar } \\
\text { ima ugodan inventar i namještaj. }\end{array}$ & 6,28 \\
\hline $\mathrm{O} 23$ & $\begin{array}{l}\text { Osoblje u izvrsnom Thalasso } \\
\text { Wellness Centru mora razumjeti } \\
\text { specifične probleme gostiju. }\end{array}$ & 6,36 & P5 & $\begin{array}{l}\text { Pribor i uređaji u izvrsnom Thalasso } \\
\text { Wellness Centru moraju biti čisti. }\end{array}$ & 6,29 \\
\hline $\mathrm{O} 24$ & $\begin{array}{l}\text { Izvrsni Thalasso Wellness Centar } \\
\text { mora brižljivo voditi računa o } \\
\text { gostima. }\end{array}$ & 6,46 & P25 & $\begin{array}{c}\text { Osoblje izvrsnog Thalasso Wellness } \\
\text { Centra brzo rješava probleme } \\
\text { gostiju. }\end{array}$ & 6,29 \\
\hline
\end{tabular}

Na temelju dobivenih rezultata istraživanja bilo je utvrđeno da je prosječna ocjena za očekivanja korisnika bila 6,7, a za percepciju 6,4 te je dobiven jaz od $-0,3$, što je ukazivalo na to da je ukupna percepcija korisnika o kvaliteti usluga wellnessa u Thalasso Wellness Centru Opatija bila vrlo blizu njihovim očekivanjima. Stoga se mogla odbaciti pomoćna hipoteza da postoji značajan jaz između percipirane i očekivane kvalitete usluga wellnessa.

Na temelju provedene analize bila je zabilježena prosječna ocjena od 6,4 za percepciju varijable „pružanje gostima individualizirane pažnje”, a za varijablu „razumijevanje specifičnih problema gostiju” bila je utvrđena prosječna ocjena 6,1. Osim toga, za varijablu „pru- žanje gostima individualizirane pažnje” bio je utvrđen i najširi negativan jaz od $-0,5$, a za varijablu „razumijevanje specifičnih problema gostiju" $-0,3$ te se u skladu s navedenim mogla odbaciti pomoćna hipoteza da klijenti percipiraju individualan pristup i razumijevanje njihovih specifičnih problema.

Provedenim istraživanjem utvrđene su relativno visoke prosječne ocjene očekivanja korisnika u vezi s pružanjem korektnih usluga već u prvom pokušaju $(6,8)$, pružanjem usluga u obećanom vremenu $(6,7)$, pouzdanošću i besprijekornom uslugom $(6,7)$ te pružanjem brze (promptne) usluge 6,5. U odnosu na čistoću i urednost centra i djelatnika utvrđene su visoke prosječne ocjene očekivanja korisnika povezane sa sljedećim varijabla- 
ma: „Osoblje izvrsnog Thalasso Wellness Centra mora biti čisto, uredno i prikladno odjeveno” (6,9), „Pribor i uređaji u izvrsnom Thalasso Wellness Centru moraju biti čisti” $(6,8)$ te „Izvrsni Thalasso Wellness Centar mora biti čist i uredan" $(6,8)$. U skladu s navedenim mogla se potvrditi hipoteza $\mathrm{H} 4$ da klijenti očekuju brze, pravodobne i korektne usluge, čistoću i urednost centra i djelatnika.

Provjera pomoćne hipoteze da postoji statistički značajna razlika između očekivanja i percepcije klijenata s obzirom na dob klijenata provedena je primjenom ttesta za nezavisne uzorke (engl. independent samples t-test) te su klijenti grupirani u prvu skupinu od 46 do 55 godina, kojih je u uzorku bilo 26 , odnosno $22,6 \%$, te u drugu skupinu u dobi od 56 do 66 godina, kojih je bilo 38 , odnosno $33 \%$ (tablica 8).

Rezultati t-testa za nezavisne uzorke pokazali su da su korisnici mlađe životne dobi imali viša očekivanja od starijih korisnika. Razlike u prosječnim ocjenama za očekivanja nisu bile statistički značajne $(p<0,05)$ pa se stoga moglo prihvatiti pomoćnu hipotezu da postoji statistički značajna razlika u očekivanjima s obzirom na dob klijenata.

Kako bi se provjerila pomoćna hipoteza da ne postoji statistički značajna razlika u percepciji korisnika s obzirom na spol, primijenjena je metoda t-testa za nezavisne uzorke (engl. independent samples t-test). Korisnici su radi provedbe testa bili grupirani u dvije skupine $s$ obzirom na spol. U prvu skupinu grupirani su bili korisnici muškog spola, kojih je u uzorku bilo 62 ili 71,3 \%, a u drugu skupinu korisnici ženskog spola, kojih je u uzorku bilo 25 ili $28,7 \%$. Rezultati t-testa prikazani su u tablici 9.
Rezultati t-testa za nezavisne uzorke pokazali su da je ženski spol imao višu prosječnu ocjenu za percepciju od muškog spola. Razlike u prosječnim ocjenama za percepciju nisu bile statistički značajne $(p>0,05)$ pa se mogla prihvatiti pomoćna hipoteza da ne postoji statistički značajna razlika u percepciji s obzirom na spol klijenata.

\section{Zaključak}

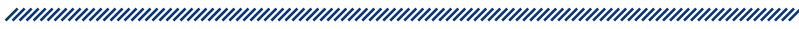

Rezultati empirijskog istraživanja pokazali su da je kvaliteta usluga wellnessa složeni, višedimenzionalni koncept, koji se temelji na programima korištenja prirodnih ljekovitih činitelja, odnosno termalnih ljekovitih voda i blata, klime i meteoroloških uvjeta, morske vode i bilja, radi poboljšanja zdravlja korisnika, rekreacije, relaksacije, zdrave i pravilne prehrane, održavanja njege i ljepote te obnove psihofizičkih sposobnosti korisnika. Time se ujedno ostvaruje temeljna značajka wellnessa u smislu posebnog načina života u skladu s prirodom, kojim se postiže ravnoteža uma, duha i tijela. Osim toga, ponuda wellness-centra trebala bi se temeljiti i na prepoznatljivosti, kvaliteti smještaja, kvaliteti prehrane, kvaliteti programa wellnessa, uravnoteženom odnosu kvalitete i cijene te primjeni sustava upravljanja kvalitetom.

$\mathrm{Na}$ kvalitetu usluga wellnessa najviše utječe osobna percepcija korisnika, odnosno njihov doživljaj kvalite-

Tablica 8. Rezultati t-testa za nezavisne uzorke - razlike u prosječnim ocjenama očekivanja u
odnosu na dob ispitanika

Tablica 9. Rezultati t-testa za nezavisne uzorke - razlike u prosječnim ocjenama percepcije u
odnosu na spol ispitanika


te, pa je stoga teško pronaći odgovarajući instrument za mjerenje kvalitete usluga wellnessa. Osiguranju kvalitete usluga wellnessa znatno pridonosi jedinstvena i prepoznatljiva ponuda, koja može utjecati na izbor budućih korisnika, kao i individualan pristup korisnicima, kojim se programi ili usluge wellnessa potpuno prilagođavaju njihovim potrebama i zahtjevima.

$\mathrm{U}$ ovome je radu za mjerenje kvalitete usluga wellnessa $\mathrm{u}$ Thalasso Wellness Centru Opatija na uzorku od $\mathrm{N}=87$ korisnika primijenjen model SERVQUAL, a kao mjerni instrument primijenjen je anketni upitnik na hrvatskom i engleskom jeziku. Na temelju dobivenih rezultata utvrđene su sociodemografske karakteristike korisnika, prosječne ocjene za očekivanja i percepciju, dobiven je SERVQUAL jaz i ocijenjena kvaliteta usluga wellnessa, utvrđena je važnost dimenzija kvalitete usluga wellnessa, značajnost razlike u prosječnim ocjenama za očekivanu i percipiranu vrijednost u odnosu na dob ispitanika (t-test) te su na temelju rezultata istraživanja dani prijedlozi za unaprjeđenje kvalitete usluga wellnessa u Thalasso Wellness Centru Opatija.

Većina korisnika bila je starije dobi, najviše umirovljenika i korisnika s visokom školom ili fakultetom, a njihova su očekivanja bila prilično visoka. Najviše prosječne ocjene za percepciju dobile su dimenzije opipljivosti i pouzdanosti, dok su najniže prosječne ocjene dobile dimenzije suosjećajnosti ili empatije. Najveći jaz utvrđen je bio kod dimenzije opipljivosti, dok je najniži jaz bio utvrđen kod dimenzije suosjećajnosti ili empatije. Prosječne ocjene za percepciju bile su dosta visoke, bez obzira na činjenicu da je samo jaz koji se odnosio na razumijevanje specifičnih problema gostiju imao pozitivan predznak 0,1, dok je za sve ostale tvrdnje jaz imao negativan predznak, a ukupan prosječan jaz iznosio je $-0,3$ što na to ukazuje da su korisnici dobro percipirali ukupnu kvalitetu usluga wellnessa, ali da još postoji mogućnost njihova daljnjeg poboljšanja u Thalasso Wellness Centru Opatija.

Dobiveni rezultati istraživanja su u odnosu na sociodemografske podatke pokazali da su korisnici mlađe životne dobi imali viša očekivanja od starijih korisnika te da je ženski spol imao višu prosječnu ocjenu za percepciju od muškog spola, što međutim nije značajnije utjecalo na prosječne ocjene očekivanja i percepciju kvalitete usluga wellnessa.

\section{Referencije}

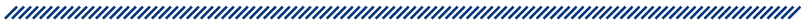

1. Lazibat T. Sustavi kvalitete i hrvatsko gospodarstvo. Ekonomski pregled. 2003, (1-2): 55-76.

2. Madžar T, Lazibat T, Mikulić J. Mjerenje kvalitete usluga u zdravstvenom turizmu. Poslovna izvrsnost. 2016, 10(1): 187-201.

3. Parasuraman A, Zeithaml VA, Berry LL. A Conceptual Model of Service Quality and its Implications for Further Research, Journal of Marketing, 1985, 49: 41-50.

4. Parasuraman A, ZeithamI VA, Berry LL. SERVQUAL: A multiple-item scale for measuring consumer percepions of service quality, Journal of Retailing, 1988, 64(1): 12.

5. Marinković V, Senić V, Kocić M, Šapić S. Investigating the impact of SERVQUAL dimensions on customer satisfaction: The lessons learnt from Serbian travel agencies. International Journal of Tourism Research. 2013, 155(2): 184-196.

6. Marković S. Kvaliteta usluga u hotelskoj industriji, koncept i mjerenje, Tourism and hospitality management. 2005, 11(1): 47-67.

7. Marković $S$, Lončarić $D$, Lončarić $D$. Service quality and customer satisfaction in health care industry - towards health tourism market. Tourism and Hospitality Management. 2014, 20(2): 155-170.

8. Marković S, Raspor S, Komšić J. Mjerenje kvalitete usluga wellnessa: case study. 13. međunarodni simpozij o kvaliteti „Kvaliteta i društvena odgovornost”, Hrvatsko društvo menadžera kvalitete, Solin, Hrvatska, 2012. str. 571-584. 


\section{APLICATION OF SERVQUAL MODEL IN SERVICE QUALITY MEASUREMENT IN THALASSO WELLNESS CENTER OPATIJA}

\author{
1 Suzana Marković \\ 1 Luka Škifić \\ 2 Aleksandar Racz \\ 1 University in Rijeka, Faculty of Tourism and Hospitality \\ Management \\ 2 University of Health Science Zagreb
}

The study results confirmed the empirical assumption of the adequacy of using the SERVQUAL model for measuring the quality of wellness services since a clear picture of the overall quality of wellness services was obtained.

The results unambiguously point to the existence of a gap between the perception and expectations of customers. Given that the highest average perception ratings went to tangible and reliable dimensions, and the lowest average ratings to compassion or empathy dimensions, the largest gap was also established in these dimensions.

The results of the empirical research can serve the management of the institution as an incentive for justifying the continuous research of wellness service quality, the satisfaction of wellness service users and job satisfaction of the wellness centre staff, by using other methods and models as well.

Keywords: service quality, wellness service quality, customer satisfaction, SERVQUAL model, Thalasso Wellness Centre Opatija tre in Opatija on a random sample of 87 respondents and analyse with method of descriptive and bivariate statistical analysis. 